\title{
Micro-célébrités "non-alignées" et la sphère publique en réseau en Syrie : fragmentation et "a- synchronization" des médias
}

"Non-aligned" online micro-celebrities and the Syrian networked public sphere fragmentation and media a-synchronization

\section{Yazan Badran and Enrico De Angelis}

\section{OpenEdition}

\section{Journals}

\section{Electronic version}

URL: http://journals.openedition.org/ctd/1822

DOI: $10.4000 /$ ctd. 1822

ISSN: 2491-1437

\section{Publisher}

Chaire Unesco Pratiques émergentes en technologies et communication pour le développement

\section{Printed version}

Date of publication: 12 November 2015

Electronic reference

Yazan Badran and Enrico De Angelis, « Micro-célébrités "non-alignées" et la sphère publique en réseau en Syrie : fragmentation et "a-synchronization" des médias ", Communication, technologies et développement [Online], 2 | 2015, Online since 11 June 2019, connection on 22 July 2020. URL : http:// journals.openedition.org/ctd/1822; DOI : https://doi.org/10.4000/ctd.1822

This text was automatically generated on 22 July 2020.

Communication, technologies et développement 


\title{
Micro-célébrités “non-alignées" et la sphère publique en réseau en Syrie : fragmentation et "a- synchronization" des médias
}

\author{
"Non-aligned" online micro-celebrities and the Syrian networked public sphere \\ fragmentation and media a-synchronization
}

Yazan Badran and Enrico De Angelis

\section{Introduction : media synchronization and the Syrian networked public sphere}

During the Arab revolts that began in 2011, new media have been used as crucial tools for expressing dissent and, to a certain extent, to organize collective actions.

Social media and digital devices enable protest movements to gain attention and disseminate information without passing through the gatekeeping and framing processes typical of traditional media. In addition, new media flatten the transaction costs needed to organize collective action, even with a scarcity of material resources and organization capabilities (Bimber, Stohl, and Flanagin, 2009).

However, the ability of social movements to use new media effectively depends on many factors. The emergence of social movements always involves the production of public representation strategies and narratives (Tilly and Wood, 2009). At the same time, as Bennet and Segerberg (2012) rightly noticed, with the advent of networked communication political demands and grievances are often shared in very personalized accounts that travel over new media platforms, rather than being handled through established political organizations. In this context, communication processes have an increasing influence on how social movements organize and structure themselves. With an increasing amount of content production, attention has become a scarce 
resource, and political actors tend to rely on those who have more social capital in order to promote their narratives through multiple media platforms.

3 For these reasons, in the context of the recent Arab uprisings, single prominent individuals emerged as playing a particularly relevant role in promoting narratives for one side or the other.

In fact, networked activism spontaneously produces people who acquire a particularly relevant social capital. In their analysis of the Egyptian Twitter sphere during the 18 days uprising against Hosni Mubarak, Johnson, Tudor and Nuseibeh (2013) have identified "authorities" and "hubs", with the former having a pivotal role in organizing protests, and the latter in disseminating information. Also, as Kraidy has described, in Syria traditional celebrities like television actors and singers have been recruited by both antagonists in order for them to get more visibility (2014).

In their analysis on social media platforms interaction, Marwick and Boyd describe the emergence of the phenomenon of "micro-celebrities". They define it as "a mind-set and set of practices in which audience is viewed as a fan base; popularity is maintained through on-going fan management; and self-presentation is carefully constructed to be consumed by others" (2011, p. 140).

Tufekci, on the other hand, speaks of "celebrity networked activism" to define the same phenomenon but in relation to political movements. Even if the dynamics of interaction with the public are very similar to those described by Marwick and Boyd, in celebrity networked activism the fan base is replaced by political activists and communities (2013).

During the recent Arab uprisings, micro-celebrities of online activism played a pivotal role in shaping and disseminating anti-regime narratives through multiple media platforms. In Egypt, the Facebook page "We are all Khaled Said" used specific discursive strategies in order to create a sense of intimacy and proximity with their public and to encourage it towards political action (Herrera, 2014). In general, some net-activists disposing of a particularly relevant amount of social capital facilitated the production of coherent and unifying narratives out of what otherwise would have been fragmented pieces of information circulating on social media platforms (De Angelis, 2014). The importance of the emergence of an economy of reputation and political microcelebrities becomes clear if we consider that online personas with a prominent status play a crucial role in facilitating, under some conditions, a political synchronization of media. In fact, micro-celebrity activists were often the points of connection between social media and traditional media at the local and the international level.

With the term "synchronization" we indicate the process through which multiple media platforms converge in producing and distributing a common, coherent narrative. Media synchronization presupposes media convergence (Jenkins, 2006), but it takes place only when new and old media create a synergy reinforcing a single frame on political events. Thus, according to Alexander and Aouragh, the demonstrations of January 2011 and those of 30 June 2013 in Egypt were accompanied by a large synchronization of media outlets supporting the ousting of Mubarak and, later, of Morsi (2014).

6 In other words, under authoritarian regimes, new media appear effective especially when a certain level of homogeneity emerges in online communication flows shaping what appears to be a single voice. What happened in the Egyptian and the Tunisian cases can be compared to a "media event" in which the framing of a political issue is 
not contested anymore, but leans towards a single and unified narrative (Dayan and Katz, 1992).

However, differently from what happened in Egypt and, to a certain extent, in Tunisia, during the Syrian uprising a synchronization of media never occurred.

In this article we intend to look at the fragmented nature of the Syrian networked public sphere that emerged after March 2011, focusing in particular on what we define here as "non-aligned" micro-celebrities.

In fact, we argue that the Syrian revolt witnessed the emergence of several online personas who base their web identities on individual narratives that work in opposition to the main narratives circulating in the Syrian political scene. In this sense, "nonaligned" micro-celebrities emerge as one of the causes, and at the same time as one of the products, of the fragmentation of the Syrian networked public sphere and the lack of a political synchronization of media.

9 As a consequence, the internet in Syria did not establish itself as neither as an inherently democratic medium nor as a tool in the hands of authorities or any specific political faction, but rather as a "Fifth Estate" (Dutton, 2009) whose effects on political processes depend on numerous strategic and non-strategic choices made by political actors.

10 Whereas "non-aligned" micro-celebrities are also to be considered as active agents in the daily reproduction of a fragmented online sphere, the main causes behind the fragmentation strictly depend on the political context of Syria. Indeed, since the beginning the Syrian uprising has been a contested political event that did not enable the creation of a synchronization of media, and this affected also the role of communication technologies in relation to political processes.

11 The Syrian regime, and in particular Bashar al-Assad, probably enjoyed more support than other Arab political leaders when the protests erupted. ${ }^{1}$ From early on, the opposition appeared divided and fragmented, both at the geographical and the political-ideological level. ${ }^{2}$ The weakness of the civil society and the unpreparedness, both at the technical and the organizational level, of media opposition activists when it came to the use of new technologies (De Angelis, 2011), are all elements that also contributed to hamper the shaping of a single, homogenous anti-regime narrative.

In this context, the Syrian regime was able to produce and distribute counterrevolution narratives among its constituencies. In a similar manner, Islamist groups and ISIS also were able to shape their particular narratives circulating in multiple media platforms.

12 Learning from the experiences of the Egyptian and Tunisian uprisings, all political actors put many efforts into the war over social networks. It is not by coincidence that on the $8^{\text {th }}$ of February 2011 the regime decided to unblock platforms like Facebook and Youtube, in what appeared at the time as a risky decision. However, this step enabled Syrian authorities to follow directly Syrian activists who were promoting actions on the web, and at the same time it facilitated the promotion of its narratives by its supporters. The Syrian Electronic Army, a community of cyber warriors established in May 2011 to attack regime's enemies on the web, also testifies to how well authorities can adapt to new technologies (Al-Rawi, 2014). 


\section{The case studies}

13 During the last four years, several online personas acquired a relevant amount of visibility within the Syrian networked public sphere. For our analysis, we will take as case studies three profiles: Jihad Makdissi, Edward Dark, and Camille Otrakji.

Jihad Makdissi was a long serving diplomat at the Syrian ministry of Foreign Affairs and his role as ministry spokesperson at the beginning of the uprising was highly publicized. He resigned from his position in December 2012, left the country and announced his divorce with the regime, but never joined any of the organized political opposition structures. He uses mainly Facebook, where his page counts about 90.000 followers. ${ }^{3}$

Edward Dark is the pseudonym and twitter handle of a Syrian online activist and journalist from Aleppo. His online activism started with the uprising, which he saw as a nonviolent popular movement. However, as the protest movement stalled and the conflict began to take a more militaristic turn, he gradually disengaged from the uprising's mainstream narrative. This gradual shift accelerated when the conflict spread to his hometown. He still tweets and writes from Aleppo, but his harshest criticism is now directed at the opposition rather than the regime. He has about 15.000 followers.

16 Camille Otrakji is a Syrian-Canadian blogger who has been active in the online Syrian sphere since 2002. He has initiated several forums for dialogue on Syrian and regional issues including a Syrian online think tank (2005), Creative Forum for Bloggers (2007), IslamComment (2010) and was heavily involved in running Joshua Landis's SyriaComment until late 2011. Since at least May 2011 he called on the demonstrations to stop and to support the Syrian president's reform agenda and to initiate dialogue with the opposition $^{4}$. His Facebook page can count on more than 2000 followers and his page is open to the general public ${ }^{5}$.

The choice of these three profiles is based on the fact that they present themselves and are perceived as political activists not completely associated with any specific political faction. Rather, they tend to promote personal views or political agendas, which, albeit can be considered at times nearer to the revolution side and at others nearer to the regime side, are generally shaped in contrast to the other main narratives.

Jihad Makdissi supports a restructuring of the regime's coercive apparatus upon which its material power stands. He envisions a political transition that presupposes a heavy redefinition of the Syrian state through a process of reconciliation between the opposition and parts of the regime.

Edward Dark and Camille Otrakji, on the other hand, see the regime, at this point of the conflict, as the only guarantor of the integrity of the State against chaos and the rise of extremist religious groups. Otrakji's hostility towards the uprising dates back to at least the beginning of the protests, which he sees as too disruptive for a state like Syria. He believes Syria can sustain a "gradual change" but not a "revolutionary change". Edward Dark's sympathies for the regime come only later, around mid 2012, when, as he says, "the uprising was hijacked" and turned into a "destruction of the state" by "extremist forces"? 
Despite their differences, the three profiles produce narratives that do not completely fit with any of the factions fighting on the Syrian political scene. Furthermore, they act on an individual basis, without adhering any political organization or group.

\section{"Non-aligned" micro-celebrities: when the Other is everywhere}

21 This is because their profiles remain strictly tethered to the individual level, without contributing to the shaping of any collective identity. They do not belong completely to any specific particular group or movement, even if they tend to define quite specific political positions for themselves. Rather, their online identities reflect the highly contested nature of the Syrian issue, in which no single faction (and its narratives) manages to attain complete solidarity.

Thus, for example, when a journalist of the satellite television al-Mayadeen asks Makdissi about his position on the Syrian political map, he answers: "after four years of this Syrian catastrophe, no one wants to hear us speaking about who is with the opposition and who is with the government. Because this is not a job where you enter at $8 \mathrm{am}$ and leave at 3pm and you say: 'I work with the opposition' or 'I work with the regime'. What we need today is a patriotic stance. And I am lucky not to be affiliated with any political party and I have a margin of maneuver bigger than others. I am still an independent, but sometimes people tend to mix independence with neutrality." 8

Makdissi presents himself as part of the opposition, but at the same time refuses to be associated with any particular party. In a similar manner, Edward Dark and Otrakji construct their online images first of all on their anti-revolution stance, but at the same time they refuse to be associated completely with pro-regime supporters. For example Otrakji says that, in a spectrum where at the extremes are the opposition and the regime, he positions himself as " $60 \%$ with the regime" . In a Facebook post he explains his position saying: “While I criticize both sides, I mostly criticize the 'revolution' side because: 1) They have been more wrong...considerably more wrong. The government (or President Assad) are clearly more experienced and knowledgeable about Syria and the region. 2) They have the big media guns...while the state tries to do propaganda, it doesn't have the loud speakers that the other side has. Whatever little energy and reach I have (this page is read by thousands each day) I will dedicate mostly to correct the biased narrative of the opposition side." ${ }^{10}$ Otrakji often refers to the parties in the conflict as "al-tarafain" (the two factions) taking distance from both of them. Other times, however, he uses "tarafna" (our side) to refer to the anti-revolution side ${ }^{11}$.

Edward Dark answers on Twitter to someone asking him about his rapprochement to the regime: "when the alternative is the collapse of ur state, slaughter of minorities+ruled by jihadi fanatics $u$ dont really have a choice". ${ }^{12}$

Their online activity is then based primarily on a disruptive approach and on criticizing the Other, albeit with different nuances, rather than supporting a specific faction.

Both Edward Dark and Camille Otrakji mainly publish content aimed at criticizing prorevolution narratives. The former focuses on denouncing rebels' crimes and misdeeds in Aleppo. This is, according to him, largely because he lives in West Aleppo, an area controlled by regime forces and often attacked by opposition fighters so he has a first 
hand experience with their violations which largely go "under-reported everywhere else"13.

only as one among other tools of communication in order to promote his political agenda. He often publishes links to the interviews he gives to TV channels and to the articles he writes, and sometimes uses posts in order to better explain his concepts and views, and to prevent people from "distorting" 15 them. In his updates he tends to stress his distance from both the regime and the opposition, referring to their errors and actions as an external observer. This distance is expressed even more clearly in some posts such as one published on 4 May 2014 in which he says: "what is absent, or maybe concealed, in the Syrian political scene is the moral and social (not political) core that supports national solutions...instead of the directly supporting the two political factions, so that this core can be a factor for a moral and social pressure on the two parts with the only aim of preserving the Syrian state in all its components, and perhaps of putting back the path towards the solution into the hands of Syrians". ${ }^{16}$

\section{Visibility strategies and public engagement}

Within networked communication, each individual must engage in "multiple mini performances that combine a variety of semiological references so as to produce a presentation of the self that makes sense to multiple audiences, without sacrificing coherence and continuity" (Papacharissi, 2011, p. 307).

In particular, we argue that, as sort of "free-rider" political activists, the management of the online pages by Makdissi, Otrakji and Edward Dark can be assimilated to those of online micro-celebrities.

As Marwick points out, micro-celebrity is a state of being famous to a niche group of people and, at the same time, it is a behavior, in the sense of "the presentation of oneself as a celebrity regardless of who is paying attention" (2013, p. 114).

Communication, technologies et développement, 2 | 2015 
31 In particular, we use here the concept of micro-celebrity to stress how Makdissi, Otrakji and Edward Dark try to maintain an ongoing public base in order to promote their personal views and opinions on the Syrian issue.

The creation of a clear online identity, in other words, enables them to attain a significant level of visibility even if they are outsiders in relation to other established political groups.

32 This implies first of all a performance of authenticity towards their public. Edward Dark presents himself as an eyewitness and an impartial reporter, writing for the online newspapers al-Monitor, and Middle East Eye. In particular, he presents himself as an independent voice living in Aleppo and following events from very close, which is especially noteworthy as events on the ground have been, since the early days of the uprising, the main area of contestation between the different narratives. As he says: "I stick to what I know best. I stick to my city, what I know about it. The people in it, the situation in it [...] so basically, I speak about the localized conflict." ${ }^{17}$ His authenticity reinforces also his critical stance against the coverage by international media. Furthermore, this physical proximity to the event also lends credence to his reporting on the mood and opinion of other Syrians, another major area of contestation between the different narratives. In his view, war reporting in traditional media is "very sterile", and people "wanted to know the view from inside. What was going on inside, and how we felt towards what was going on." ${ }^{18}$ In fact, many of his articles focus exclusively on gauging and reporting the public's mood inside Syria ${ }^{19}$.

Jihad Makdissi presents himself as a political expert and a professional diplomat, often invoking his professional experience in explaining and commenting on the intricacies of international diplomacy on Syria ${ }^{20}$. This professional image and authenticity is accentuated further by stressing that he "resigned" his diplomatic post and left the Syrian regime "respectfully", rather than "defected" 21 . Makdissi also uses social media to update followers on foreign trips, invitations and meetings related to his work ${ }^{22}$. In this way, he attempts to shape a transparent relationship with his public by reporting in detail on his political activities and meetings.

Camille Otrakji, on the other hand, builds up his online identity presenting himself as a moderator of discussions on Syrian issues. In fact, the idea of transforming his Facebook page into a forum "open to anyone" can be traced back to his personal history as a creator of several online forums dedicated to Syria since $2005^{23}$. When he abandoned the moderation of the comment section on Joshua Landis' blog SyriaComment because, according to him, of harsh attacks by opposition supporters, he decided to move to social networks. He stresses that the polarization made it impossible for him to use the forum platforms, such as Creative Forum, which he relied on before the uprising.

The focus on discussion is at the core of his Internet strategies and at the same time an aim in itself. In fact, if we examine the relationship between posts and comments on his profile, we find that he dedicates a particular attention to interacting with the public. Between 16 and 30 of April 2015, for example, he publishes 157 comments over 52 updates. In addition, the content itself is packaged in order to provoke discussion with his public. As he says in the interview, he recently realized that unconsciously he was using a very specific strategy: publishing content critical of the opposition, and then trying to moderate especially the comments of pro-regime supporters ${ }^{24}$. In this way, he provokes opposition supporters to intervene and at the same time tries to control 
excesses by pro-regime supporters during the discussion. Also, he dedicates several posts to accuse pro-opposition activists of refusing dialogue with him, especially on their pages. Thus, his Facebook page becomes a stage from which he denounces specific opposition personalities of having him blocked on social networks or refusing to accept criticism. For example, in a recent post on Facebook he says: "After four years, there is one very important thing that Syria analysts need to know but they still do not. President Assad reads criticism everyday. He seeks it. The revolutionaries and opposition leaders (and I closely know many) are unable to tolerate reading a long article that challenges their understanding of Syria." ${ }^{25}$

While the majority of people commenting on his page are pro-regime supporters, he does not cease trying to attract to his page people with different perspectives. With this purpose, not only does he engage people directly into the discussion through tagging on Twitter and Facebook, but he also selects the content to publish in order to force them to take it into consideration. He says, for example, that he tends not to use sources that he knows are not considered credible by opposition supporters ${ }^{26}$.

Building up his profile as a moderator, even if it is generally perceived as much more on the regime side than that of the opposition, enables Otrakji to attract an audience transforming his page in a daily forum that in his opinion is "open" and where "anyone is welcome" ${ }^{27}$. Moreover, the topic of discussion (and especially the refusal by opposition supporters to engage with it) reinforces the critical content he publishes against the different sides of the conflict, and especially the revolution side. The very fact that they do not accept dialogue with him is then presented as another proof of the flawed nature of political actors and groups.

In general, the three personalities present themselves as independent figures with an audience of both pro and anti-regime camps, and, especially in the case of Edward Dark and Camille Otrakji, a significant number of foreign observers and journalists. They also stress their openness to interact with this varied audience. Edward Dark, for example, says that he receives constructive feedback about his reporting on rebel crimes from opposition activists on the other side of the town. This feedback, according to him, helps build a more nuanced background to some events, and adds missing details on violations by the Syrian Army as well ${ }^{28}$.

In the case of Makdissi and Otrakji, where their pages play host to these discussions, the self-professed desire to interact with a mixed public translates itself into expanding the borders of acceptable speech to include some of the "inevitable" anger, and emotional language ${ }^{29}$.

39 Makdissi also points out that many of his pro-regime followers did not leave his page when he broke ranks with the regime. He says that he intentionally chooses his media appearances in order to reach different audiences. On this point he gave the example of two television interviews he made after a conference in Cairo in January 2015 and that he published on his page: One was done with al-Mayadeen news channel, with a majority of its audience from the regime loyalist camp, while the other with Sky News Arabia, with a majority of its audience from the opposition camp ${ }^{30}$. 


\section{Conclusions}

The prominence acquired by what we have called "non-aligned" micro-celebrities reflects the fragmentation and a-synchronization of the Syrian media field after the 2011 uprising.

With the term "non-aligned" we described a specific set of practices and strategies at the base of the construction of the online persona.

First, "non-aligned" micro-celebrities act as networked individuals, rather than coordinate with others in the production of collective political projects and narratives. Second, they construct their online identities mainly in opposition to the other main narratives competing today in the Syrian sphere. Third, they adopt strategies typical of online micro-celebrities in order to attract different publics to their pages. In particular, they try to engage with different publics in order to promote their views on a large political spectrum. In this operation, the rhetoric of the need of discussion and moderation has a particularly relevant place, giving them legitimacy as autonomous actors and, especially, in highlighting the flaws and the problems of the main political antagonists on the Syrian scene.

In so doing, while in other contexts of the so-called "Arab Spring" online microcelebrities often contributed to strengthening and disseminating unitary narratives necessary for collective mobilizations, in Syria "non-aligned" micro-celebrities on the contrary tend to weaken these narratives and, as such, also the possibility of a media synchronization.

3 In particular, Edward Dark and Camille Otrakji play an important role as counternarrators of the revolution, opting for a disruptive approach in which "stability", "the state", and the logic of the "lesser evil" replace other forms of solidarity towards any of the involved political factions.

It is very important here to stress that, as we have seen above, Edward Dark, Jihad Makdissi and Camille Otrakji often refer to the fact that they give voice to (and target) the so-called "silent majority" in Syria, rather than the established political actors, i.e. the opposition and the regime in particular. This enables them to claim that they represent larger constituencies, even if they act on an individual level. Thus, Edward Dark puts the accent on the fact of giving visibility to the mood and the state of common people in Aleppo, and Jihad Makdissi often refers to "Syrians" as a separate entity from the opposition or the regime, putting their interests at the core of his individual political efforts.

5 In the same way, Camille Otrakji describes how in social networks it is only staunch pro-regime and pro-opposition supporters who tend to be active, while the others (the majority) tend not to interact or they do not even want to talk about politics ${ }^{31}$. In other words, they tend to stress that the highly contested nature of the Syrian issue is an element that undermines any claims by the existing political actors to represent the will of the Syrian people ${ }^{32}$. 


\section{BIBLIOGRAPHY}

References

Alexander, Anne, \& Aouragh, Miriyam (2014). Arab Revolutions: Breaking Fear| Egypt's Unfinished Revolution: The Role of the Media Revisited. International Journal of Communication, 8 , 890-915.

Al-Rawi, Ahmed K. (2014). Cyber Warriors in the Middle East: The Case of the Syrian Electronic Army. Public Relations Review, 40(3). http://doi.org/10.1016/j.pubrev.2014.04.005

Bennett, W. Lance, \& Segerberg, Alexandra (2012). The Logic of Connective Action. Information, Communication \& Society, 15(5), 739-768. http://doi.org/10.1080/1369118X.2012.670661

Bimber, Bruce, Stohl, Cynthia, \& Flanagin, Andrew J. (2008). Technological change and the shifting nature of political organization. In Andrew Chadwick \& Philip N. Howard (Eds.), Routledge Handbook of Internet Politics (pp. 72-85). New York: Routledge. Retrieved from http://ictlogy.net/ bibliography/reports/projects.php?idp=1474

Castells, Manuel (2006). The Network Society: From Knowledge to Policy. In Manuel Castells \& Gustavo Cardoso (Eds.), The Network Society: From Knowledge to Policy. Washington: Center for Transatlantic Relations.

Dayan, Daniel, \& Katz, Elihu (1992). Media Events: The Live Broadcasting of History. Cambridge, MA: Harvard University Press.

De Angelis, Enrico (2011). The State of Disarray of a Networked Revolution. Sociologica, (3), 1-24. http://doi.org/10.2383/36423

De Angelis, Enrico (2015). L'espace politique virtuel avant et après la chute de Moubarak : une critique des réseaux sociaux digitaux en Egypte. Égypte/Monde arabe, 3(12). Retrieved from http:// ema.revues.org/3456?lang=en

Dutton, William H. (2009). The Fifth Estate Emerging Through the Network of Networks. Prometheus, 27(1), 1-15.

Gerbaudo, Paolo (2012). Tweets and the Streets: Social Media and Contemporary Activism. London: Pluto Press. Retrieved from http://www.press.uchicago.edu/ucp/books/book/distributed/T/ bo21638666.html

Herrera, Linda (2014). Revolution in the Age of Social Media: The Egyptian Popular Insurrection and the Internet. London: Verso Books.

Hinnebusch, Raymond (2012). Syria: from "authoritarian upgrading” to revolution? International Affairs, 88(1), 95-113. http://doi.org/10.1111/j.1468-2346.2012.01059.x

Jenkins, Henry (2006). Convergence Culture: Where Old and New Media Collide. New York University Press.

Johnson, Ginger A., Tudor, Brant, \& Nuseibeh, Hasan (2013). 140 Characters or Less: How Is the Twitter Mediascape Influencing the Egyptian Revolution? Middle East Journal of Culture and Communication, 6(1), 126-148. http://doi.org/10.1163/18739865-00503006

Kraidy, Marwan M. (2015). The Politics of Revolutionary Celebrity in the Contemporary Arab World. Public Culture, 27(1), 161-183. http://doi.org/10.1215/08992363-2798391 
Marwick, Alice, \& Boyd, Danah (2011). To See and Be Seen: Celebrity Practice on Twitter. Convergence: The International Journal of Research into New Media Technologies, 17(2), 139-158. http:// doi.org/10.1177/1354856510394539

Marwick, Alice (2013). Status Update: Celebrity, Publicity, and Branding in the Social Media Age. New Haven: Yale University Press.

Papacharissi, Zizi (2011). Conclusion: A Networked Self. In Zizi Papacharissi (Ed.), A Networked Self: Identity, Community, and Culture on Social Network Sites (pp. 304-318). New York: Routledge.

Parks, Malcolm R. (2011). Social Network Sites as Virtual Communities. In Zizi Papacharissi (Ed.), A Networked Self: Identity, Community, and Culture on Social Network Sites (pp. 105-123). New York: Routledge.

Tilly, Charles, \& Wood, Lesley J. (2009). Social Movements, 1768-2008. Boulder: Paradigm Publishers. Tufekci, Zeynep (2013). "Not This One" Social Movements, the Attention Economy, and Microcelebrity Networked Activism. American Behavioral Scientist, 57(7), 848-870. http://doi.org/ 10.1177/0002764213479369

\section{NOTES}

1. On this point, Hinnebusch says: "Compared to those of other Arab republics, the regime enjoyed a foreign policy congruent with public opinion, a young president still enjoying the benefit of the doubt and seen as preferable to alternatives in the regime, security forces more loyal and effective than elsewhere, a weaker civil society and a more fragmented opposition" (2012, p. 106).

2. On the fragmentation of Syrian opposition see, for example, "Anything but Politics: The State of Syria's Political Opposition”, International Crisis Group, Middle East Report N. 146, 17 October 2013: $\quad$ http://www.crisisgroup.org/ /media/Files/Middle\%20East\%20North\%20Africa/ Iraq\%20Syria\%20Lebanon/Syria/146-anything-but-politics-the-state-of-syrias-politicalopposition.pdf

3. Interview with Yazan Badran, 25 April 2015.

4. See, for example Qifa Nabki, “Talking about a Revolution: An Interview with Camille Otrakji”, Qifa Nabki, 2 May 2011: http://qifanabki.com/2011/05/02/camille-otrakji-syria-protests/

5. Regarding his followers on Facebook he says: "I have 1500 friends and 5000 followers. Friends are about $80 \%$ of readers. But my profile is open, many read without being Facebook friends. I see from the likes I get that about half of them are not friends"., Interview with Enrico De Angelis, 11 May 2015.

6. Interview with Enrico De Angelis, 26 April 2015.

7. Interview with Yazan Badran, 27 April 2015.

8. Interview on 24 January 2015, al-Mayadeen: https://www.youtube.com/watch?v=cOEgcDINO_Y

9. Interview with Enrico De Angelis, 26 April 2015.

10. Post published on Facebook on 21 of April 2015: https://www.facebook.com/camille.otrakji/ posts/10153777481402977

11. See, for example, the post published on Facebook on 1 May 2015: https://www.facebook.com/ photo.php?fbid=10153804629032977

12. Tweet published on 2 April 2015: https://twitter.com/edwardedark/status/ 583406714902446080

13. Interview with Yazan Badran, 27 April 2015.

14. https://www.facebook.com/camille.otrakji/posts/10153810878157977 
15. Interview with Yazan Badran, 25 April 2015.

16. https://www.facebook.com/makdissi/posts/10152041293181606

17. Interview with Yazan Badran, 27 April 2015.

18. Ibid.

19. See, for example, "Aleppo's Christians see regime as last hope", Al-Monitor, 23 March 2015: http://www.al-monitor.com/pulse/originals/2015/03/syria-christians-aleppo-regimecommunity-is.html

and "Syrian regime ignores supporters' rising anger", Al-Monitor, 7 October 2014: http://www.almonitor.com/pulse/originals/2014/10/homs-suicide-bombing-children-regime-syria-warprotests.html

20. See, for example, the post published on Facebook on 1 December 2014, in which he explains in details the difference between "Air Exclusion Zone" and "No-Fly Zone" and the political implications of each: https://www.facebook.com/makdissi/posts/10152463065851606

21. Interview with Yazan Badran, 25 April 2015.

22. Ibid. See, for example, the post published on Facebook on 29 April 2015: https:// www.facebook.com/makdissi/posts/10152784748376606 and the post published on Facebook on 20 April 2015: https://www.facebook.com/photo.php?fbid=10152775008361606

23. Interview with Enrico De Angelis, 26 April 2015.

24. Ibid.

25. Post published on Facebook on 17 March 2015: https://www.facebook.com/photo.php? fbid $=10153676778027977$

26. Ibid.

27. Ibid.

28. Interview with Yazan Badran, 27 April 2015.

29. Interview with Yazan Badran, 25 April 2015; Interview with Enrico De Angelis, 26 April 2015.

30. Interview with Yazan Badran, 25 April 2015.

31. Interview with Enrico De Angelis, 26 April 2015.

32. For the role of populist discourse within new media strategies of contemporary collective movements see Gerbaudo (2012).

\section{ABSTRACTS}

During the Arab uprising in 2011, new media have been used as effective tools to express dissent and mobilize people. Flattening the transaction costs necessary to organize collective actions, new technologies have introduced innovative forms of political struggle, based on networked individualism and "connective action" (Bennett and Segerber, 2012) rather than on institutions and hierarchical organizations. During the Arab uprisings, the "synchronization" (Alexander and Aouragh, 2014) between old and new media enabled in some cases the emergence of counterhegemonic narratives capable to create a large consensus towards the ongoing mobilizations. However, the limits of web 2.0 in terms of public sphere dynamics as well as a space to organize collective actions have also emerged.

In this article we will focus in particular on the case of the Syrian networked public sphere. We argue that in Syria the virtual sphere appears since the beginning as a contested space on which pro-democracy activists, differently from other Arab contexts, were not able to impose their 
narratives. Rather than a connected networked public sphere, a "self-directed mass communication" mode (Castells, 2005) became prevalent resulting in fragmented networks.

In order to describe the dynamics of the fragmented Syrian networked public sphere, we will focus in particular on what we define here as "non-aligned" micro-celebrities. We argue that the Syrian revolt witnessed the emergence of online personas shaping their web identities on individual narratives that worked in opposition to the main collective narratives circulating in the Syrian political scene.

In this sense, the relevance of "non-aligned" micro-celebrities has to be considered as one of the causes and at the same times of the products of the shaping of a networked public sphere characterized by fragmentation and media a-synchronization, rather than coordination and media synchronization.

Pendant les révoltes arabes de 2011, les nouveaux médias ont été utilisés comme instruments efficaces d'expression et de mobilisation. En réduisant les coûts nécessaires à l'organisation d'actions collectives, les nouvelles technologies ont introduit des formes innovantes de lutte politique basées sur un individualisme en réseau et sur ce que Bennet et Segerber (2012) appellent "connective action", et non sur des institutions structurées ou des organisations hiérarchiques. Pendant les révoltes arabes, une "synchronisation" (Alexander et Aouragh, 2014) entre médias nouveaux et traditionnels a permis, dans certains cas, l'émergence de récits antihégémoniques capables de créer un large consensus en faveur des mobilisations. Mais les limites $\mathrm{du}$ "web 2.0" en termes de dynamiques de la sphère publique et comme espace au sein duquel organiser des actions collectives sont également apparues.

Dans cet article, nous nous focaliserons en particulier sur le cas de la sphère publique en réseau syrienne. Nous maintenons qu'en Syrie la sphère virtuelle apparaît dès le début des protestations comme un espace contesté au sein duquel les activistes, à la différence de ce qui s'est produit dans d'autres pays arabes, ne sont pas parvenus à imposer leurs récits. Au lieu d'une sphère publique basée sur la connexion, les réseaux en Syrie apparaissent fragmentés et basés sur la visibilité d'individus spécifiques.

Pour décrire les dynamiques propres à cette fragmentation, nous nous arrêterons en particulier sur ce qu'on a défini comme des micro-célébrités "non-alignées" : la révolte syrienne a vu l'émergence de personnes en ligne qui construisent leur identité virtuelle sur la base de récits individuels, en opposition avec les principaux récits collectifs circulant sur la scène politique syrienne après 2011.

En ce sens, l'importance des micro-célébrités "non-alignées" doit être considérée comme l'une des causes, et en même temps comme l'une des conséquences, de l'émergence d'une sphère publique en réseaux caractérisée par la fragmentation et une manque de synchronisation entre les médias, plutôt que sur la coordination et la collaboration.

\section{INDEX}

Keywords: Syria, networked public sphere, online micro-celebrities, media synchronisation, social movements, networked individualism, online identities

Mots-clés: Syrie, sphère publique en réseau, micro-célébrités en ligne, synchronisation des médias, mouvements sociaux, individualisme en réseau, identités en ligne 
AUTHORS

YAZAN BADRAN

yazan.badran@gmail.com

ENRICO DE ANGELIS

edeangelis@gmail.com 